\title{
ISOLATION OF DIPHTHEROIDS FROM NON-GONOCOCCAL URETHRITIS*
}

\author{
BY \\ G. FURNESS $†$ \\ Twyford Laboratories, London, N.W.10 \\ AND \\ G. W. CSONKA \\ Central Middlesex Hospital, London
}

Since annual returns of patients with non-gonococcal urethritis (NGU) have been made to the Ministry of Health, the number of cases reported has increased from 11,552 in 1952 to 25,001 in 1963 (Ministry of Health, 1952, 1963). The condition has variously been attributed to Staphylococcus aureus (Conger, 1964), mycoplasma (Dienes and Edsall, 1937; Klieneberger-Noble, 1959), Inclusion blennorrhoea virus (Dunlop, Jones, and Al-Hussaini, 1964; Dunlop, Al-Hussaini, Garland, Treharne, Harper, and Jones, 1965), and the T forms of mycoplasma. Yet with the exception of the T forms which have been isolated from 60 to 80 per cent. of patients (Shepard, 1954; Ford, Rasmussen, and Minken, 1962; Csonka, Williams, and Corse, 1966), other agents have been isolated from only a minority of cases. Therefore, either the condition is due to the $\mathrm{T}$ forms or the majority of infections are caused by an unknown agent or agents.

It is, however, exceptionally difficult to infect healthy animals experimentally with mycoplasma (Chu, 1954) without first inducing trauma (Klieneberger-Nobel and Cheng, 1955) or introducing a superimposed virus infection (Mooser, 1951; Klieneberger-Nobel, 1954). Thus there is evidence that some mycoplasmas are potential pathogens which initiate a clinically recognizable condition only after the animal has incurred some initial stress. Chu (1954) has also observed in the field that avian infectious bronchitis, a disease normally lasting 2-3 weeks, is changed into a chronic illness lasting several months by a superimposed mycoplasma infection and has suggested that infections with mycoplasmas are usually associated with another agent. $T$ forms are found in the urine of over 50 per cent. of the normal female and 10-20 per cent. of the normal male population (Csonka and

* Received for publication February 19, 1966 + Present address: Dept. of Virology, M. D. Anderson Hospital,
Houston, Texas. others, 1966), which suggests that the $T$ forms alone are not the cause of NGU but that they can combine with some other micro-organisms which initiate the infection.

The lack of success in observing micro-organisms microscopically in the exudate of NGU indicated that the symbiont might be a virus. Yet NGU can be treated with antibiotics. The only known antibiotic-sensitive viruses belong to the trachomaL.G.V. group, which produce inclusions in cells, and inclusions have been demonstrated in urethral scrapings (Harkness, 1950; Durel, Roiron-Ratner, and Borel, 1951; Siboulet, 1952; Thygeson, 1954; Brisou, 1954; and several others). These viruses also vary in their susceptibility to antibiotics in vivo and in vitro (T'ang, Chang, Huang, and Wang, 1957; Jawetz and Hanna, 1960). In previous attempts to isolate these organisms from NGU, antibiotics were added to the material examined to eliminate bacterial contamination (Ford, 1956, 1958; Csonka and Furness, 1960; Morton, Gillespie, and Wilson, 1964), and the possibility exists that they also killed the pathogen.

By aseptic techniques it has been shown that the urethra of the normal male is sterile (Harkness, 1950; Klieneberger-Nobel, 1959) even though the anterior portion and orifice have a rich saprophytic flora (Harkness, 1950; Freundt 1956). Therefore, by suitable techniques, it should be possible to obtain uncontaminated material from the urethra of patients with NGU. In the present study the urethra of males was irrigated with antibiotic-free phosphate buffered saline (PBS) which was examined for the aetiological agent of NGU by inoculating aliquots into the yolk sac of fertile eggs and on to blood agar plates.

\section{Material and Method}

Both the NGU patients and controls were untreated males who presented themselves at the Central Middlesex 
Hospital. In all cases of NGU, infection with Neisseria gonorrhoea and Trichomonas vaginalis was excluded. The controls had no history or evidence of urethritis and wished to confirm that they were free from venereal disease.

Urethral Irrigation.-A 12-in. cannula, 0.109 in. diam., shortened to 8 in. was snugly sheathed in a nylon tube $7 \cdot 25$ in. long to form a sterile double cannula (Portland Plastics, Hythe, Kent) and fitted on to a $2 \mathrm{ml}$. Luer syringe which was filled with PBS previously warmed to room temperature.

Before insertion into the urethra, the cannula was withdrawn about $0.5 \mathrm{in}$. inside the nylon sheath so that the sheath entered the urethra first and so protected the cannula from contamination with commensals. After the sheath had penetrated about 1.5 in., the cannula was gently pushed a further $0.5-0.75$ in. beyond its tip and the PBS slowly injected. The washings were then aspirated, the cannula replaced with a 1.5 in. No. 19 needle, and eggs and media were immediately inoculated. Smears were prepared. Normally $0 \cdot 8-1.0 \mathrm{ml}$. washings were recovered.

Media and Solution.-Phosphate buffered saline (PBS) without calcium and magnesium was prepared according to the formula of Lwoff, Dulbecco, Vogt, and Lwoff (1955) and 10 per cent. calf serum blood agar, tellurite blood agar, Wright's nutrient broth, and Hiss's serum water sugars by the methods described in the "Handbook of Practical Bacteriology" (Mackie and McCartney, 1948).

Penicillin Sensitivity Tests.-Blood agar plates, were flooded with a broth culture and dried, and a disk containing 1 unit penicillin (Mast Laboratories, Liverpool) was placed in the centre before incubating at $37^{\circ} \mathrm{C}$.

Fertile Eggs.-Fertile eggs from a flock which was never medicated were incubated as required for 5-6 days at $99 \cdot 5^{\circ} \mathrm{F}$.

\section{Isolation and Identification of Diphtheroids}

Providing a sufficient volume of urethral washings was recovered both on primary inoculation and on passage of yolk sac homogenates $0.2 \mathrm{ml}$. was injected into the yolk sac of each of three 5 to 6-day-old fertile eggs which were incubated at $37^{\circ} \mathrm{C}$. At death or 12 days after inoculation, the yolk sac was harvested, serum blood agar plates inoculated, and smears prepared, stained by Gram's method and examined. If diphtheroids were identified, the yolk sac was stored in screw-capped bottles at $-20^{\circ} \mathrm{C}$. until their identity was confirmed by culture. Otherwise the yolk sac was homogenized with $5 \mathrm{ml}$. PBS for one minute in an M.S.E. blender and the homogenate passaged. Not more than three passages were made. The serum blood agar plates were incubated aerobically and anaerobically. The purity of the culture was confirmed and single colonies were plated out on tellurite blood agar, inoculated into nutrient broth, and stained by Gram's method and by Albert's stain for metachromatic granules. The overnight broth culture was examined for motility and inoculated into Hiss's serum water sugars. All cultures were incubated at $37^{\circ} \mathrm{C}$. for not less than 5 days; growth in unfermented sugars was always confirmed. Only Gram-positive, non-motile bacilli producing dark-coloured to black colonies on tellurite blood agar were termed diphtheroids.

As a control, eggs and media were inoculated with PBS used in the experiment.

\section{Results}

The urethral washings of 64 patients with nonspecific urethritis and of twenty normal controls were examined by injecting $0.2 \mathrm{ml}$. into the yolk sac of 5 to 6-day-old fertile eggs and by plating out on serum blood agar or blood agar plates which were incubated at $37^{\circ} \mathrm{C}$. for 5 days both aerobically and anaerobically. Sterility of the PBS, fertile eggs, and media was controlled by inoculating the PBS into eggs and onto media from the same batches as for the experiments. None was contaminated. Even though the plates were heavily inoculated within 5 minutes of recovering the inoculum from the patient and concurrently with the inoculation of the eggs, no diphtheroids were isolated and only an occasional colony of coagulase-negative staphylococci was seen.

Staphylococci and other bacteria not only caused death but putrefaction of the fertile egg within 24 hrs. Coagulase-negative staphylococci were isolated from 34.4 per cent. patients and 30 per cent. controls (Table I). With the exception of one egg, the number of positive results was not increased by passaging the homogenized yolk sacs and only all the eggs from two controls and two patients were infected, thus terminating the investigations. Therefore it would appear that these organisms readily multiplied in the egg, even a single staphylococcus killing the embryo within $24 \mathrm{hrs}$ and that normally their numbers were few, averaging less than one organism in $0.2 \mathrm{ml}$. washings. The similarity in the

TABLE I

\begin{tabular}{|c|c|c|c|c|}
\hline \multirow{2}{*}{ Persons } & \multicolumn{4}{|c|}{ Persons harbouring: } \\
\hline & \multicolumn{2}{|c|}{ Gram-negative Rods } & \multicolumn{2}{|c|}{ Staphylococci } \\
\hline Series No. & No. & Per cent. & No. & Per cent. \\
\hline $\begin{array}{ll}\text { NSU } & 64 \\
\text { Controls } & 20\end{array}$ & $3 \dagger$ & $\begin{array}{l}4 \cdot 7 \\
0\end{array}$ & $\begin{array}{r}22 * \\
6 *\end{array}$ & $\begin{array}{l}34 \cdot 4 \\
30 \cdot 0\end{array}$ \\
\hline
\end{tabular}

* All eggs infected in two cases only

$t$ All eggs infected 
percentage of patients and controls harbouring these saprophytes suggested that this small number was due to a fault inherent in the aseptic technique for obtaining urethral washings in which no bactericidal agents were incorporated in the PBS used for irrigation. Similarly, the Gram-negative rods which killed the eggs of three patients were considered contaminants.

Diphtheroids. - There remained for further examination at least one egg inoculated from each of 59 of the 64 patients and eighteen of the twenty controls. After 48 to 72 hrs incubation, eggs from two controls and 39 patients commenced to die, their embryos and yolk sacs being typically haemorrhagic without any evidence of disintegration or putrefaction. A diphtheroid was isolated in each case on either serum blood agar or blood agar, and its identity confirmed. The yolk sacs from fertile eggs alive on the 12th day after inoculation were harvested, homogenized in $5 \mathrm{ml}$. PBS and passaged by the yolk sac inoculation of $0.2 \mathrm{ml}$. into each of three 5 to 6 -day-old fertile eggs. Unfortunately, the homogenates from six of the 20 patients, negative on first passage, were lost, leaving those from fourteen patients only. Of these, eleven were shown to be infected, nine on the second and two on the third passage; three remained negative, as did the sixteen controls. Thus, passage significantly increased the number of isolates from NSU patients.

By this technique, out of 53 patients, fifty $(94 \cdot 3$ per cent.) were shown to be infected with diphtheroids as against two (11.1 per cent.) of eighteen controls (Table II), suggesting that these organisms are associated with the condition. An estimate of the concentration in the washings was made by titrating serial 10-fold dilutions prepared in PBS in fertile eggs. Embryos inoculated with up to $10^{-3}$ dilution died, suggesting that there were at least 1,000 diphtheroids per $\mathrm{ml}$.
On the death of the embryo, diphtheroids were recovered by inoculating blood agar plates with yolk and amniotic and allantoic fluids. The strains varied in their ability to grow on artificial media, growing best on blood agar enriched with 10 per cent. calf serum. Their growth tended to diminish on subculture and it was not improved by adding fluids from fertile eggs.

All the strains were Gram-positive, non-motile rods producing dark-coloured to black colonies on tellurite blood agar. Six strains were anaerobic, the remainder being facultative anaerobes. They varied in their morphology, some having metachromatic granules and in their biochemical reactions which confirmed that they were not homogeneous (Table III). The two strains isolated from controls were similar in their biochemical reactions to those isolated from five patients. Therefore these strains may be contaminants from the flora of the anterior urethra. Ten NGU strains, picked at random, were

TABLE III

BIOCHEMICAL REACTIONS OF DIPHTHEROIDS

\begin{tabular}{|c|c|c|c|c|c|c|}
\hline \multirow{2}{*}{$\begin{array}{c}\text { Number of } \\
\text { Strains }\end{array}$} & \multirow{2}{*}{ Series } & \multicolumn{5}{|c|}{ Results of Tests on Strains } \\
\hline & & Glucose & Sucrose & Maltose & Lactose & Starch \\
\hline $\begin{array}{r}* 5 \\
1 \\
1 \\
13 \\
1 \\
1 \\
7 \\
1 \\
1 \\
1 \\
\ddagger 2\end{array}$ & $\begin{array}{c}34 \\
\text { Patients }\end{array}$ & $\begin{array}{l}t \\
t \\
t \\
t \\
t \\
- \\
\overline{\mathbf{A}} \\
\mathbf{A} \\
\mathbf{A} \\
\mathbf{t} \\
\mathbf{A}\end{array}$ & $\begin{array}{l}t \\
t \\
t \\
t \\
- \\
t \\
\overline{\mathbf{A}} \\
\mathbf{A} \\
\mathbf{t} \\
\mathbf{A}\end{array}$ & $\begin{array}{l}t \\
t \\
- \\
- \\
- \\
\overline{-} \\
\overline{\mathbf{A}} \\
\mathbf{A} \\
\mathbf{A} \\
\mathbf{A}\end{array}$ & $\begin{array}{l}t \\
- \\
- \\
- \\
- \\
- \\
\bar{A} \\
\mathbf{A} \\
- \\
-\end{array}$ & $\begin{array}{l}t \\
t \\
t \\
- \\
-t \\
\bar{t} \\
- \\
- \\
-\end{array}$ \\
\hline$* 2$ & $\stackrel{2}{\text { Controls }}$ & $\dagger$ & $t$ & $t$ & $t$ & $t$ \\
\hline
\end{tabular}

* One in each group fermented mannitol. The remainder w negative.

$t$ Acid and Gas.

A Acid only.

- Negative or doubtful.

$\ddagger$ The strain isolated before treatment and after relapse of patien 4 weeks later gave these reactions.

TABLE II

EFFECT OF PASSAGE IN FERTILE EGGS ON THE NUMBER OF ISOLATIONS OF DIPHTHEROIDS FROM URETHRAL WASHINGS

\begin{tabular}{|c|c|c|c|c|c|c|c|c|}
\hline \multirow{3}{*}{\multicolumn{2}{|c|}{ Series }} & & \multirow{3}{*}{ Passage } & \multirow{3}{*}{ No. } & \multicolumn{4}{|c|}{ Persons Examined } \\
\hline & & & & & \multicolumn{2}{|c|}{ With Diphtheroids } & \multicolumn{2}{|c|}{ Without Diphtheroids } \\
\hline & & & & & No. & Per cent. & No. & Per cent. \\
\hline N.G.U. & . & $\cdots$ & $\begin{array}{l}1 \mathrm{st} \\
2 \mathrm{nd} \\
3 \mathrm{rd}\end{array}$ & $\begin{array}{l}59 \\
14^{*} \\
5\end{array}$ & $\begin{array}{r}39 \\
9 \\
2\end{array}$ & $\begin{array}{l}66 \cdot 1 \\
90 \cdot 6 t \\
94 \cdot 3 t\end{array}$ & $\begin{array}{c}20^{*} \\
5 \\
3\end{array}$ & $\begin{array}{l}33 \cdot 9 \\
9 \cdot 4 t \\
5 \cdot 7 t\end{array}$ \\
\hline Controls & $\cdots$ & $\cdots$ & $\begin{array}{l}\text { 1st } \\
2 \text { nd } \\
3 \text { rd }\end{array}$ & $\begin{array}{l}18 \\
16\end{array}$ & $\begin{array}{l}2 \\
0\end{array}$ & $\begin{array}{l}11 \cdot 1 \\
11 \cdot 1\end{array}$ & $\begin{array}{l}16 \\
16\end{array}$ & $\begin{array}{l}88 \cdot 9 \\
88 \cdot 9\end{array}$ \\
\hline
\end{tabular}

* Eggs from six patients were lost.

t Includes those from previous passage but excludes the six lost. 
tested for their sensitivity to penicillin. All were sensitive to less than one unit.

Effect of Treatment with Antibiotics on Infection with Diphtheroids. - The organisms continued to be isolated from three patients who did not respond to treatment. They could no longer be isolated from five cases who responded, until symptoms recurréd in two cases, 4 and 8 weeks later, when they were again recovered (Table IV). The strain recovered from the patient who had a recurrence of symptoms 4 weeks after cure gave similar biochemical reactions to that isolated before treatment (Table III). Therefore, although the number of patients was small, the evidence suggested that there is a correlation between infection with diphtheroids and symptoms of NSU.

TABLE IV

EFFECT OF TREATMENT WITH TETRACYLINES ON THE ISOLATION OF DIPHTHEROIDS FROM NSU PATIENTS

\begin{tabular}{c|c|c|c}
\hline $\begin{array}{c}\text { No. of } \\
\text { Patients }\end{array}$ & $\begin{array}{c}\text { Clinical } \\
\text { Condition }\end{array}$ & \multicolumn{2}{|c|}{ Isolation of Diphtheroids } \\
\hline $5^{*}$ & $\begin{array}{c}\text { Recovered } \\
\text { Unchanged }\end{array}$ & $\begin{array}{c}\text { Pes } \\
\text { Yes }\end{array}$ & $\begin{array}{c}\text { Post-treatment } \\
\text { Yes }\end{array}$ \\
\hline
\end{tabular}

* Recurred in two patients and diphtheroids were isolated again.

Susceptibility of Fertile Eggs to Diphtheroids.During the isolation of diphtheroids by passage, eggs inoculated from the same washings or even yolk sac homogenates remained alive after others had died (Table V). This suggested that not only might diphtheroids vary in their ability to kill the embryo, but that some fertile eggs might be more resistant. Therefore, two strains were tested for their ability to kill 5 to 6-day-old fertile eggs. From broth cultures, 10-fold serial dilutions were prepared in PBS and five eggs per dilution were each inoculated with $0.2 \mathrm{ml}$., the number of viable organisms inoculated being determined by the drop count method of Miles and Misra (1938).

TABLE V

RESISTANCE OF FERTILE EGGS TO INFECTION WITH DIPHTHEROIDS IN URETHRAL WASHINGS

\begin{tabular}{c|c|c|c|c}
\hline $\begin{array}{c}\text { No. of } \\
\text { Patients }\end{array}$ & Passage & $\begin{array}{c}\text { No. of Eggs } \\
\text { Inoculated }\end{array}$ & $\begin{array}{c}\text { No. of Eggs Infected } \\
\text { with Diphtheroids }\end{array}$ \\
\hline 1 & $\begin{array}{c}\text { 1st } \\
\text { 2nd }\end{array}$ & 2 & Dead & Alive \\
\hline 10 & $\begin{array}{c}\text { 1st } \\
\text { 2nd }\end{array}$ & $\begin{array}{l}1 \\
3\end{array}$ & 1 \\
\hline 2 & $\begin{array}{c}\text { 1st } \\
\text { 2nd }\end{array}$ & 2 & 2 & 1 \\
\hline 3rd & 3 & 1 & 1 \\
\hline
\end{tabular}

Both strains killed the largest number of embryos within $48 \mathrm{hrs}$ of inoculation. One strain A was obviously more virulent; even so a small inoculum of either strain could be lethal (Table VI). The eggs varied greatly in their susceptibility to the organisms, especially to strain B, relatively large inocula failing to kill some embryos. Therefore the failure to isolate diphtheroids without passage may be due, in some cases, to variability in the resistance of the eggs and not to the number of organisms inoculated.

TABLE VI

EFFECT OF THE NUMBER OF DIPHTHEROIDS INOCULATED ON THE SURVIVAL OF CHICK EMBRYOS

\begin{tabular}{|c|c|c|c|c|c|c|c|c|c|}
\hline \multirow{2}{*}{$\begin{array}{c}\text { Strain of } \\
\text { Diphtheroids }\end{array}$} & \multirow{2}{*}{\multicolumn{2}{|c|}{$\begin{array}{l}\text { *Days to } \\
\text { Death }\end{array}$}} & \multicolumn{7}{|c|}{ Estimated No. of Diphtheroids Inoculated } \\
\hline & & & $1.1 \times 10^{6}$ & $1 \cdot 1 \times 10^{5}$ & $1 \cdot 1 \times 10^{4}$ & $1 \cdot 1 \times 10^{3}$ & $1 \cdot 1 \times 10^{2}$ & $1.1 \times 10^{1}$ & $1 \cdot 1$ \\
\hline \multirow[t]{3}{*}{$\mathbf{A}$} & & $\begin{array}{r}1 \\
2 \\
3 \\
4 \\
7 \\
10 \\
12\end{array}$ & $\begin{array}{l}\frac{4}{1} \\
= \\
=\end{array}$ & $\begin{array}{l}4 \\
1 \\
= \\
=\end{array}$ & $\frac{1}{二}$ & $\begin{array}{l}\frac{2}{2} \\
= \\
\frac{1}{1}\end{array}$ & $\begin{array}{l}\frac{1}{2} \\
\frac{2}{2}\end{array}$ & $\begin{array}{l}2 \\
\frac{1}{1} \\
= \\
=\end{array}$ & $\begin{array}{l}\overline{2} \\
\frac{1}{\bar{Z}} \\
\overline{1}\end{array}$ \\
\hline & \multirow{2}{*}{ Eggs } & No. dead & \multirow{2}{*}{$5 / 5$} & \multirow{2}{*}{$5 / 5$} & \multirow{2}{*}{$5 / 5$} & \multirow[t]{2}{*}{$5 / 5$} & \multirow[t]{2}{*}{$5 / 5$} & \multirow[t]{2}{*}{$4 / 5$} & \multirow[t]{2}{*}{$4 / 5$} \\
\hline & & No. inoc. & & & & & & & \\
\hline \multirow{4}{*}{ B } & \multirow{2}{*}{\multicolumn{2}{|c|}{$\begin{array}{l}1 \\
2 \\
3 \\
5 \\
9\end{array}$}} & & $2 \times 10^{5}$ & $2 \times 10^{4}$ & $2 \times 10^{3}$ & $2 \times 10^{2}$ & $2 \times 10^{1}$ & 2 \\
\hline & & & & $\begin{array}{l}\overline{3} \\
\mathbf{2} \\
\end{array}$ & $\begin{array}{r}1 \\
1 \\
1 \\
1 \\
\end{array}$ & $\frac{\overline{2}}{\frac{7}{2}}$ & $\frac{\overline{2}}{\frac{7}{2}}$ & $\bar{z}$ & $\begin{array}{l}\overline{1} \\
\overline{-}\end{array}$ \\
\hline & \multirow{2}{*}{ Eggs } & No. dead & & \multirow{2}{*}{$5 / 5$} & \multirow{2}{*}{$4 / 5$} & \multirow{2}{*}{$4 / 5$} & \multirow{2}{*}{$4 / 5$} & \multirow{2}{*}{$2 / 5$} & \multirow{2}{*}{$1 / 5$} \\
\hline & & No. inoc. & & & & & & & \\
\hline
\end{tabular}

* Candled daily.

Days with no deaths omitted. 
T. Forms of Mycoplasma.-Broth cultures of three strains of the T. form of mycoplasma isolated from NGU patients (Csonka and others, 1966) were inoculated into the yolk sac of fertile eggs and passaged. The embryos remained alive and there was no evidence of transformation to diphtheroids.

\section{Discussion}

Many bacteria and viruses can be isolated by inoculating infected material into fertile eggs in which they multiply and kill the embryo (Beveridge and Burnet, 1946). The mycoplasmas of human origin which grow but fail to kill the egg (Keller and Morton, 1956; Shepard, 1960) are an exception.

The anterior urethra contains many saprophytic bacteria as commensals and some contamination of the washings could be expected when no antibiotics were employed. Saprophytic staphylococci were isolated from 34.4 per cent. of the NGU patients and 30 per cent. of the controls, but the estimated concentration was normally less than five organisms $/ \mathrm{ml}$. washings and few were isolated by direct inoculation of blood agar plates. It is therefore reasonable to conclude that they were contaminants due to faults inherent in the technique. Even so, our method of obtaining material from the urethra is practicable and the possibility of the aetiological agent of NGU being susceptible to antibiotics in vitro but not in vivo was excluded.

Bacteria were recovered from every egg in which the embryo died. Therefore, although mycoplasmas must have been present in some of the washings, in no instance could death of the embryos be attributed solely to these organisms.

Diphtheroids were isolated from 94.3 per cent. of the NGU patients and $11 \cdot 1$ per cent. (2 of 18 ) controls. The two organisms from the controls and five ( 14.7 per cent.) of the 34 NGU strains examined for their biochemical reactions were similar, suggesting that these also may be contaminants. Even if these 14.7 per cent. cases are classed as negative, diphtheroids were isolated from nearly 80 per cent. of the patients. An accurate estimate of the concentration of the organisms and so of the severity of the infection was not obtained because of their inability to grow on media on first isolation and to variations in the susceptibility of fertile eggs. There were at least $1,000 / \mathrm{ml}$. washings. Thus, their inability to grow on media on first isolation cannot be attributed to too few diphtheroids in the inoculum but rather to some unknown growth requirement. It seems likely that they become less fastidious during passage in the egg and this supposition is supported by their tendency to revert to poorer growth when subcultured from one serum blood agar plate to another.
That they were not $T$. forms of mycoplasma which transformed to the diphtheroid form was confirmed by passaging three pure $T$. form cultures in eggs without effect.

These organisms were Gram-positive, pleomorphic, non-motile rods, many of which produced gas from glucose. They have been termed "Diphtheroids" because the production of gas from sugars does not exclude them from the Corynebacteriaceae (Prévot 1960). Prévot (1960) has found that one sero-type of his anaerobic and microaerophilic corynebacteria consisted of several biochemically different strains. It is therefore possible that many of our strains which differed biochemically belong to the same sero-type and also have the common property of being potentially pathogenic. That they are associated with the condition is supported by our inability to isolate them on clinical cure, by their return on relapse, and by their continued presence in patients who do not respond to treatment.

This investigation still does not exclude the possibility that the presence of an antibiotic-sensitive virus in the eggs is masked by the diphtheroids or that $T$ forms and diphtheroids alone can be the aetiological agent. It seems more probable, however, that there is a synergistic relationship between these organisms and that these strains of diphtheroids can establish an environment suitable for some $T$ forms of mycoplasma to flourish in the male urethra and together produce the symptoms of NGU.

However, further investigations may show that the diphtheroids are commensals, and Koch's postulates have not yet been fulfilled; the isolation of these organisms which like the TRIC viruses are sensitive to penicillin, has amply demonstrated that, whenever possible, contamination should be eliminated by aseptic techniques rather than by antimicrobial substances.

\section{Summary}

The urethras of males were irrigated with phosphate buffered saline by an aseptic technique which reduced contamination of the washings with commensals in the anterior urethra to a minimum, thus avoiding the use of antibiotics.

Fertile eggs and blood agar plates were inoculated with washings from 64 patients with non-gonococcal urethritis and twenty controls.

Saprophytic staphylococci were isolated from 34.4 per cent. NGU cases and 30 per cent. controls. They were considered contaminants as their concentration was usually less than 5 per $\mathrm{ml}$.

Diphtheroids which would not grow on media on first isolation were isolated from 94.3 per cent. patients and $11 \cdot 1$ per cent. controls by passage in 
the yolk sac of fertile eggs. However, 14.7 per cent. of strains from NGU patients gave similar biochemical reactions to those from the controls and may be contaminants. The failure of previous investigations to isolate them in ovo may be explained by their sensitivity in vitro to 1 unit penicillin or less, and the importance of controlling contamination by aseptic techniques rather than by antimicrobial agents is stressed.

That they are associated with NGU is supported by their disappearance on clinical cure, by their return or relapse, and by their continued presence in patients who do not respond to treatment. Attempts to transform $T$ form cultures to the diphtheroid form by passage failed and the relationship of the diphtheroids to the $T$ forms of mycoplasma is discussed.

We wish to thank Mrs Margaret Luke and $\mathrm{Mr}$ M. Walne for their excellent technical assistance. The work of one of us (G.W.C.) was supported by a grant from the Medical Research Council.

\section{REFERENCES}

Beveridge, W. I. B., and Burnet, F. M. (1946). M.R.C. Spec. Rep. Ser., No. 256.

Brisou, J. (1954). Paper read at "International Symposium on Non-Gonococcal Urethritis, Monaco". WHO Publication VDT/129.

Chu, H. P. (1956). "10th World's Poultry Congress: Report of Proceedings, 1954", Department of Agriculture for Scotland, Edinburgh. p. 246.

Conger, K. B. (1964). Med. Clin. N. Amer., 48, 767.

Csonka, G. W., and Furness, G. (1960). Brit. J. vener. Dis., 36, 181.

_- Williams, R. E. O., and Corse, J. (1966.) Lancet, 1, 1292.

Dienes, L., and Edsall, G. (1937). Proc. Soc. exp. Biol. $(N . Y$.), 36, 740.

Dunlop, E. M. C., Jones, B. R., and Al-Hussaini, M. K. (1964). Brit. J. vener. Dis., 40, 33.

-_, Al-Hussaini, M. K., Garland, J. A., Treharne, J. D., Harper, I. A., and Jones, B. R. (1965). Lancet, 1, 1125.

Durel, P., Roiron-Ratner, V., and Borel, L. J. (1951). Presse méd., 59, 789.

Ford, D. K. (1956). Brit. J. vener. Dis., 32, 184. (1958). Ibid., 34, 53.

-, Rasmussen, G., and Minken, J. (1962). Ibid., 38, 22. Freundt, E. A. (1956). Ibid., 32, 188.

Harkness, A. H. (1950). "Non-Gonococcal Urethritis", p. 68. Livingstone, Edinburgh.

Jawetz, E., and Hanna, L. (1960'. Proc. Soc. exp. Biol. $(N . Y), 105,320$.

Keller, R., and Morton, H. E. (1956). J. Bact., 67, 129.

Lwoff, A., Dulbecco, R., Vogt, M., and Lwoff, M. (1955). Virology, 1, 128.

Mackie, T. J., and McCartney, J. E. (1948). "Handbook of Practical Bacteriology", 8th ed. Livingstone, Edinburgh.
Miles, A. A., and Misra, S. S. (1938).J. Hyg. (Camb.), 38, 732.

Ministry of Health (1952-1963). "Annual Reports of the C.M.O.” Brit. J. vener. Dis.

Mooser, H. (1951). Arch. ges. Virusforsch., 4, 207.

Morton, R. S., Gillespie, E. H., and Wilson, M. A. (1964). J. clin. Path., 17, 114.

Klieneberger-Nobel, E. (1954). Biol. Rev., 29, 154. - (1959). Brit. J. vener. Dis., 35, 20.

and Cheng, K. K. (1955). J. Path. Bact., 70, 245.

Prévot, A. R. (1960). Ergebn. Mikrobiol., 33, 1.

Shepard, M. C. (1954). Amer. J. Syph., 38, 113. (1960). Ann. N.Y. Acad. Sci., 79, 397.

Siboulet, A. (1952). J. Urol. méd. chir. (Paris), 58, 408.

T'ang, F. F., Chang, H. L., Huang, Y. T., and Wang, K. C. (1957). Chin. med. J., 75, 429.

Thygeson, P. (1954). Paper read at "International Symposium on Non-Gonococcal Urethritis, Monaco". WHO Publication VDT/129.

\section{L'isolement des diphtérö̈des des urétrites non-gonococciques \\ RÉSUMÉ}

L'urètre des patients a été lavé avec une solution de sérum physiologique de phosphate tamponnée employant une technique aseptique qui a réduit la contamination de ces lavages par les commensaux dans l'urètre antérieur à son minimum évitant ainsi l'usage des antibiotiques. Des œufs fertiles et des milieux de culture de sang et d'agar ont été inoculés par les lavages obtenus de 64 malades souffrant d'urétrite non-gonococcique (UNG) et aussi de 20 contrôles.

Des staphylocoques saprophytiques ont été isolés de 34,4 pour cent des cas d'UNG et 30 pour cent des contrôles. Ils ont été considérés comme ayant contaminés les lavages car leur concentration était généralement moins que 5 par ml.

Des diphtéroïdes qui ont refusé de pousser sur les milieux de cultures au premier isolement ont été isolés chez 94,3 pour cent des malades et 11,1 pour cent des contrôles par passage dans la membrane vitelline des œufs fertiles. Cependant 14,7 pour cent des souches provenant des malades souffrant d'UNG ont donné des réactions biochimiques similaires à celles obtenues des contrôles et ces réactions pourraient être dues à la contamination. L'échec des recherches précédentes de les isoler in ovo peut être expliqué par leur sensibilité in vitro à une unité ou moins de pénicilline, et l'importance du contrôle de la contamination par des techniques aseptiques plutôt que par des agents antimicrobiens est soulignée.

Leur élimination après la cure clinique, leur retour après une rechute, et aussi leur présence continue chez les malades qui ne répondent pas au traitement donnent la preuve qu'elles sont associées à l'UNG. Les essais de transformer des cultures de forme $\mathrm{T}$ à la forme diphtéroïde par passages ont échoué et la relation des diphtéroïdes aux mycoplasmes de forme $T$ est discutée. 